\title{
13 Portuguese
}

Maria Filomena Gonçalves

\subsection{Orthography and Orthoepy}

\begin{abstract}
In 1990, Portugal, Brazil, and the then-five (now six) African countries whose official language is Portuguese (Cape Verde, Guinea-Bissau, São Tomé and Príncipe, Angola, and Mozambique) signed the Acordo Ortográfico de 1990 (A090), an international agreement whose objective it is to give Portuguese - a pluricentric language - a common orthography. The A090 has gone through some difficulties and is now official only in four Lusophone countries (Portugal, Brazil, Cape Verde, and São Tomé and Príncipe). However, after centuries without an official regulation, of a unilateral Reform (Portugal), and of the $20^{\text {th }}$ century marked by the disagreement between Portugal and Brazil, the more the political discourse emphasizes the role of the AO90 for the "unidade da lingua" and for its international prestige, the more the enforcement of the AO90 in the Lusophone countries suffers from problems or uncertainties. The A090 is thus a receptacle of graphic solutions that reflect orthoepic differences between the two, already-established national norms (European and Brazilian).
\end{abstract}

Keywords: Portuguese, Lusophony, orthography, spelling, orthoepy, pronunciation, standardization, modernization, phonology, pluricentricity

\section{Introduction}

The current situation of the implementation of the AO90 in the countries of the socalled "lusofonia" can only be understood by looking at its historical antecedents and at the problems subjacent to the graphic standardization of the Portuguese language. The term lusofonia conveys the "ideia de um bloco linguístico formado por Portugal, as suas colónias e o Brasil” with more than 240 million speakers; yet, it is also the object of controversies (Castro 2010; Faraco 2012). The idea of unifying Portuguese orthography was not new given that the "demanda" (Castro/Duarte/ Leiria 1987) for a uniform graphic system has been around for many centuries. It was not resolved in 1911 when Portugal approved the Bases para a Unificação da Ortografia, a unilateral initiative that caused diplomatic tension with Brazil, independent since 1822. Lasting the entire $20^{\text {th }}$ century, this disagreement between Portugal and Brazil led to the establishment of two national (graphic) norms - European and Brazilian Portuguese. It was a situation that somehow reflected the idea that Portuguese had stopped being a monocentric language.

https://doi.org/10.1515/9783110458084-029 